Vol. 3, No. 2, 2016

UDC 338.2:658

M. Nashkerska,

$\mathrm{PhD}$, Associate Professor,

N. Mykytiuk,

$\mathrm{PhD}$, Associate Professor,

Lviv Polytechnic National University

\title{
IMPROVING THE METHODS FOR COMPANY'S LIQUIDITY ASSESSMENT
}

\begin{abstract}
In this paper, authors analyze existing approaches to assessment of company's liquidity and solvency, and identify inconsistencies and inaccuracies of these approaches, particularly in relation to the organization of assessment. They suggest an improved method for calculation of indices that form the basis of liquidity assessment.
\end{abstract}

Keywords: assets, balance sheet liquidity, assessment, liabilities, liquidity indices

\section{Formulation of the problem}

The level of solvency of a company, defined as its ability to meet its current liabilities, is a matter of utmost importance to its owners, investors, lenders, and employees, as well as to various government authorities. Several liquidity indices are used to assess the solvency of a company. An accurate assessment of the company's solvency depends upon correct methods of calculating liquidity indices. Any inaccuracy in methods will lead to distortion in results and incorrect assessment of the company's financial state. Therefore, decisions made by owners or lenders on the basis of such inaccurate assessment may be inefficient. Contemporary studies on this issue have not shaped a universal systemic approach to the organization and methods of company's liquidity assessment; there are various inaccuracies and inconsistencies related to the calculation of liquidity indices.

\section{Analysis of recent research and publications}

The theory and methods of liquidity indices calculation have been addressed in a number of studies by Ukrainian and foreign scientists. Important contributions to this issue have been made by researchers in Ukraine (L. Lakhtionova, Ye. Mnykh, H. Savytska, Yu. Tsal-Tsalko, I. Blank, M. Korobov, L. Kovalenko, A. Zahorodnii,
A. Poddieriogin and others) and internationally (J. Van Horne, J. Wachowicz, J. Shim and J. Segal, J. Richard, E. Helfert, E. Brigham and others). Despite the vast research background, there is a need for methodological implementation of theoretical knowledge into practice.

The purpose of the research is to improve the methodological approach to liquidity indices calculation by means of grouping assets and liabilities by the level of their marketability and the term to maturity, respectively.

\section{Presentation of the main material}

Calculation of liquidity indices is one of the easiest methods of assessing a company's solvency, or ability to meet its current liabilities within a reasonably short period of time. This group of indices is calculated by comparing company's current assets against its current liabilities. Due to this, liquidity indices are used in official methodology of government agencies for assessing a company's financial state. However, both official methodology and scientific research papers demonstrate a number of inconsistencies related to the methods of liquidity indices calculation as well as the terminology used. Let us highlight a few of these.

The Order of the Ministry of Economics of Ukraine "On Amendments to Methodological Guidelines for Detecting Signs of Insolvency of Companies and Signs of Activities Aimed at Concealment of Bankruptcy, Fraudulent Bankruptcy or Deliberate Bankruptcy" (No.1361 of 26.10.2010) prescribes to calculate the current (overall) liquidity ratio of a company as current assets divided by loan capital (current and longterm liabilities). The document states that "an 
increase in this index signifies a positive trend for a company", which is, in our opinion, incorrect [1].

A high current liquidity ratio may also indicate an excessive and unjustified accumulation of current assets, compared to the amount of loan capital.

At the same time, the Order of Ministry of Finance of Ukraine "On Approval of Methodology for the Analysis of Financial and Commercial Operations of Public Sector Companies' (No.170 of 14.02.2006) names the same ratio, which "reflects the number of current asset units per unit of longterm and current liabilities", as "an overall liquidity ratio" [2]. The document does not contain any indication of a regulatory value for this ratio.

There is another index reflecting a ratio of current assets to current liabilities, which is used in documents mentioned above, under the name of "coverage ratio". The regulatory value for coverage ratio is different in the two documents. The Methodological Guidelines No.1361 indicate that "an increase in this index signifies a positive trend for a company" [1], and the Order of Ministry of Finance specifies a regulatory value range of 1.0 to 1.5 [2].

In scientific studies (A. H. Zahorodnii, H. I. Kindratska, M. S. Bilyk, O. O. Sheremet, Ciaran Walsh and others) [3, 4, 5], an index reflecting a ratio of current assets to current liabilities is called a "current liquidity ratio". A recommended regulatory value of this index falls within the range of 1.0 to 2.0.

The Methodological Guidelines No.1361 also suggest calculating a "quick liquidity ratio" [1]. For this ratio, only a portion of current assets, namely cash at bank and in hand, marketable securities, and accounts receivable, are considered against current liabilities. In scientific works, this index is also known as "interim liquidity ratio", "critical liquidity ratio", "operating liquidity ratio", and "acid test ratio". The regulatory value of this index differs across documents and publications.

Liquidity is defined as an ability of a company to convert its current assets into money with minimal loss of value, in order to pay off its short-term liabilities.

The assessment of the company's liquidity includes:

- measuring the balance sheet liquidity,

- calculation and analysis of liquidity indices.

Consequently, to maintain the optimum state of liquidity, a company needs to continuously maintain an objectively justified ratio of assets and liabilities on its balance sheet.

In order to measure the liquidity of a company balance sheet, assets need to be categorized by the level of marketability and liabilities by the term to maturity.

Based on the level of marketability, assets may be broken down into the following categories:

Assets ready for use $\left(\mathrm{A}_{1}\right)$ are all amounts of money and equivalent instruments, i.e., money that may be readily used for operational transactions. This includes short-term deposits and securities considered "cash equivalent" (balance sheet assets, Section 2, line 1160: Current financial investments; line 1165: Cash and cash equivalents; line 1166: Cash; line 1167: Bank accounts).

Assets promptly convertible $\left(\mathrm{A}_{2}\right)$ are assets that require some period of time to convert them into money. This category includes accounts receivable (balance sheet assets, Section 2, lines 1125 to 1155$)$. However, only receivables that are expected to be received within 12 months may be included. Therefore, all contracts with customers need to be analyzed in order to categorize receivables by terms of payment.

Assets slowly convertible $\left(\mathrm{A}_{3}\right)$ are assets that require a significant amount of time to convert them into money, with a considerable risk of loss of value. This category includes inventory, except for outgoing inventory, and overdue receivables.

Assets not easily convertible $\left(\mathrm{A}_{4}\right)$ are assets required for the company's long-term operations. This category includes assets from Section 1 of the balance sheet ("Non-current assets").

Categorization of certain other types of current assets, such as "Deferred expenses", "Other current assets", and balance sheet Assets Section 3: "Non-current assets held for sale, and disposal groups", remains a subject of debate.

Deferred expenses are costs that have been incurred in the present reporting period, but are subject to be reported as expenses in future periods. As benefits are received over time, these costs will be written off gradually and reported as expenses. Such expenses include rent payments, pre-paid subscription for periodicals, license fees, insurance premiums, costs related to launching new production sites or new products etc. In the accounting process, these expenses are accumulated by debiting account 39, Deferred expenses. As benefits are received with time, these 
expenses are written off by respectively crediting the same account 39. Still, not all of the deferred expenses are written off within 12 months. For instance, costs related to launching new production sites or new products may be written off over several years. For the purposes of assessing liquidity of this kind of assets, they may be categorized by write-off period into short-term expenses (deferred expenses that will be written off within 12 months) and longterm expenses (deferred expenses that will be written off over a period longer than 12 months). I. V. Vyhivska, E. H. Melnyk suggest to record long-term deferred expenses under account 185 . The breakdown of deferred expenses into short-term and long-term expenses is illustrated in Fig. 1 [6].

Based on this breakdown, short-term deferred expenses may be categorized as assets slowly convertible $\left(\mathrm{A}_{3}\right)$, and long-term expenses as assets not easily convertible $\left(\mathrm{A}_{4}\right)$.
There is no unanimous approach among scientists as to the categorization of "Other current assets". Balance sheet line 1190, Other current assets reflects the value of current assets that cannot be identified as a separate line by relevance indicators, nor can they be included into any other article of the "Current assets" section. This line reflects the value of company's monetary instruments in national and foreign currencies, as well as debit record of VAT accounts (debit balance: $331,332,643,644)$.

Sub-accounts 331 and 332 are used for recording the balance and transactions in monetary instruments (in national and foreign currencies) kept at the company cashier's desk: pre-paid vouchers for health resorts and recreation centers, post stamps, contract stamps, travel tickets and vouchers for business travel etc.

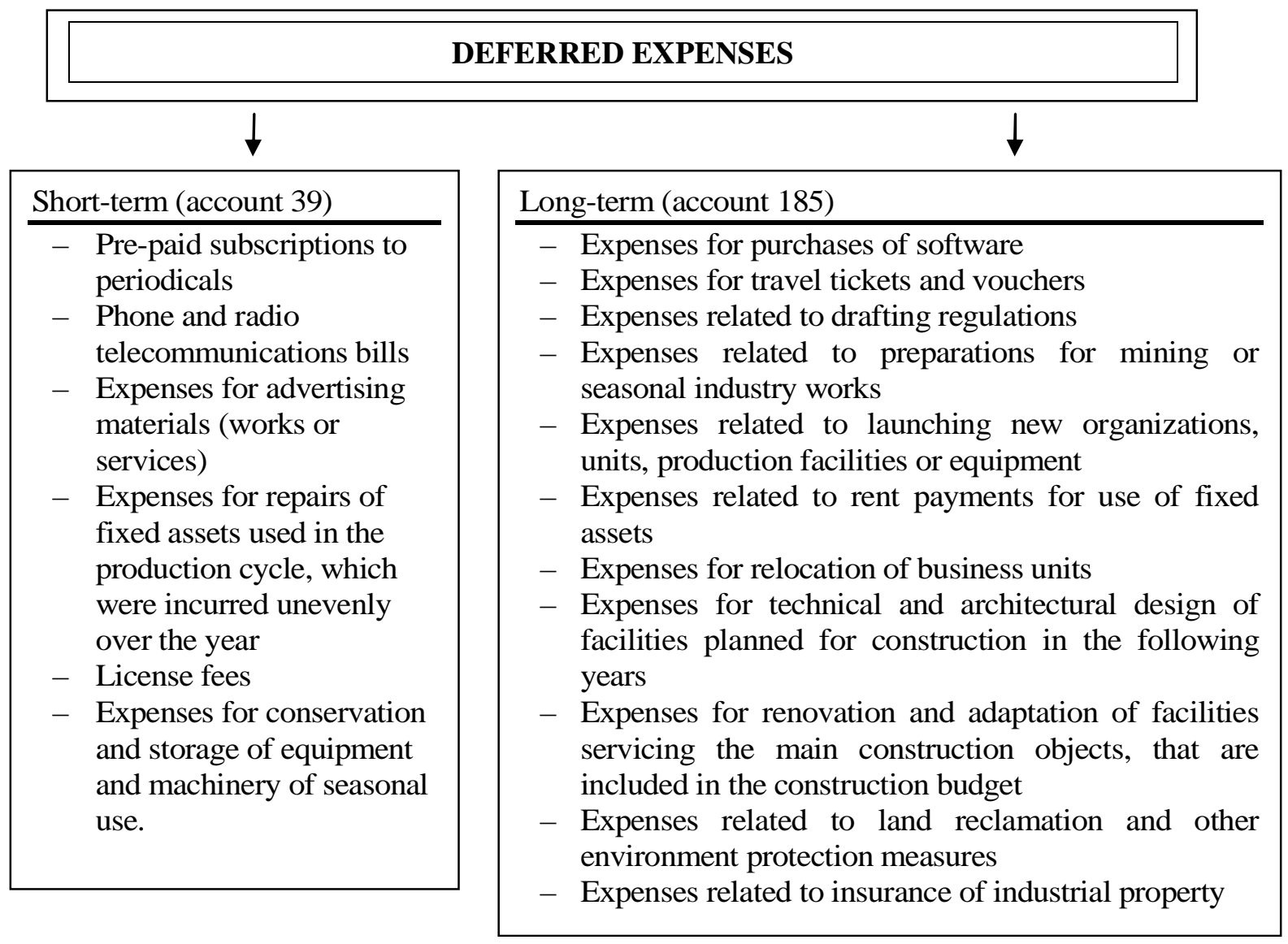

Fig. 1. Categorization of deferred expenses

Sub-account 643 is used for recording the amounts of value added tax calculated from advance payments received for products, goods, intangible assets, works or services that are yet to be delivered or performed. In other words, it serves for VAT payable records.

Sub-account 644 is for recording value added tax credit, or VAT amounts that are 


\section{Nashkerska, N. Mykytiuk}

deductible under the applicable tax laws in cases when an advance payment to the seller is the first event in a buying transaction.

Based on the purposes of sub-accounts mentioned, we consider it appropriate to include "Other current assets" into the second category, i.e., Assets promptly convertible $\left(\mathrm{A}_{2}\right)$.

Section 3 "Non-current assets held for sale, and disposal groups" reflects the value of noncurrent assets and disposal groups that are held for sale, as identified and regulated by the national Accounting Regulation (Standard) 27: "Noncurrent assets held for sale and discontinued operations"; these are recorded under account 286 [7]. In accordance with the $\operatorname{AR}(\mathrm{S}) 27$, a disposal group is a collection of assets that are scheduled for sale or transfer by any other means in a single transaction, and liabilities that are directly linked to such assets and will be transferred (paid) as a result of the same transaction.Pursuant to paragraph 1 of the $\operatorname{AR}(S) 27$ [7], non-current assets and disposal groups are identified as "held for sale" if the following conditions are met:

- economic benefits are expected from their sale rather than from their use for the intended purpose; condition;

- they are suitable for sale in their present

- their sale is expected to be completed within one year from the date of their designation as "held for sale";

- the terms of their sale are consistent with regular terms of sale for similar assets;

- their immediate sale poses a high risk, for example, when the company has a specific plan or a strict sale contract, they are actively offered on the market at a price that matches their actual fair value.

At the same time, the regulation envisages that "the period to the completion of sale may be extended beyond one year in case such extension is mandated by circumstances beyond the company's control, and the company is continuing to follow the sale plan". This means that whenever an asset remained unsold for longer than a year, it may have been improperly classified as held for sale, or it appeared difficult to sell due to lack of demand.

At the same time, there may be assets recorded under account 286, which are very unlikely to be sold; alternatively, if an asset no longer meets the criteria set for non-current assets held for sale, it should be transferred into the noncurrent assets section. If, however, the company still intends to sell these assets (e.g., some of the fixed assets that are no longer necessary for company operations), they may be recorded under sub-account 117, Other non-current tangible assets, or sub-account 184, Other non-current assets, of the synthetic record account 18, Long-term receivables and other non-current assets. Their value is then reflected under Assets Section 1 of the balance sheet [8].

Appropriate identification and recording of non-current assets held for sale has a significant impact on company's liquidity assessment. In general, Section 3, "Non-current assets held for sale, and disposal groups" should be included into the assets slowly convertible $\left(\mathrm{A}_{3}\right)$ category in its entirety. However, there is a possibility that some of the assets designated as "held for sale" (and recorded under account 286) do not, in essence, meet the criteria for designation as non-current assets held for sale. If detailed information sources are accessible, the analyst responsible for categorization of assets by the level of marketability should perform a thorough review of all items recorded under account 286 . Should some of the non-current assets be identified as noncompliant with the criteria of "held for sale" designation, the analyst should include them into assets not easily convertible $\left(\mathrm{A}_{4}\right)$ and suggest that accountants make appropriate corrections in the records.

Assets of the first three categories (ready for use, promptly convertible, and slowly convertible) change constantly over the course of the present operational period; therefore, they are classified as company's current assets. These three asset groups $\left(A_{1}, A_{2}\right.$, and $\left.A_{3}\right)$ are used for calculation of relative liquidity indices.

Liabilities on the balance sheet are categorized by the term to maturity.

Immediate liabilities $\left(\mathbf{L}_{1}\right)$ are company's obligations that require timely payments. These include: accounts payable with vendors and contractors, taxes and duties (and other mandatory payments) payable, wage arrears (lines 1615 to 1650, inclusive).

Short-term liabilities $\left(\mathbf{L}_{\mathbf{2}}\right)$ are liabilities maturing within 12 months. This category of liabilities includes short-term bank loans (line 1600), promissory notes issued (line 1605), current 
portion of long-term borrowings (line 1610). In our opinion, current provisions (line 1660), deferred income (line 1665), other current liabilities (line 1690), and Section 4, "Liabilities associated with assets held for sale and disposal groups" should also be included into this category.

Long-term liabilities $\left(\mathbf{L}_{\mathbf{3}}\right)$ are obligations under long-term loans and borrowings, and other liabilities extending over a longer time period. This category is made up of liabilities with a term to maturity exceeding one year, which matches Liabilities Section 2 on the balance sheet.

Permanent liabilities $\left(\mathbf{L}_{\mathbf{4}}\right)$ are obligations towards capital owners. This category matches Liabilities Section 1 on the balance sheet.

The balance sheet liquidity of a company is calculated on the basis of values identified above. The balance sheet liquidity is a state where the corresponding categories of assets and liabilities are matched in a manner that allows the company to meet its liabilities of different terms to maturity with assets of appropriate marketability level [3].
The state of absolute balance sheet liquidity is achieved if the following conditions are met:

- Assets ready for use are greater than or equal to immediate liabilities,

- Assets promptly convertible are greater than or equal to short-term liabilities,

- Assets slowly convertible are greater than or equal to long-term liabilities, and

- Assets not easily convertible are less than permanent liabilities.

When conditions one, two, and three are met, the last condition is also met. This state indicates that the company has sufficient working capital throughout the assessed time period. If at least one of the statements is not true, it means that the balance sheet liquidity of the company is not ensured.

Table 1 below summarizes the categorization criteria for assets and liabilities, their appropriate balance sheet items, and conditions of absolute balance sheet liquidity.

Criteria and conditions of balance sheet liquidity

Table 1

\begin{tabular}{|c|c|c|c|c|}
\hline $\begin{array}{l}\text { Categorization of } \\
\text { assets }\end{array}$ & Balance sheet line codes & $\begin{array}{l}\text { Categorization of } \\
\text { liabilities }\end{array}$ & Balance sheet line codes & $\begin{array}{c}\text { Conditions of } \\
\text { absolute } \\
\text { balance sheet } \\
\text { liquidity } \\
\end{array}$ \\
\hline $\begin{array}{l}\text { Assets ready for use } \\
\left(A_{1}\right)\end{array}$ & 1160,1165 & $\begin{array}{l}\text { Immediate } \\
\text { liabilities }\left(\mathrm{L}_{1}\right)\end{array}$ & $\begin{array}{l}\text { 1615-1650 (except for } \\
1630)\end{array}$ & $\mathrm{A}_{1} \geq \mathrm{L}_{1}$ \\
\hline $\begin{array}{l}\text { Assets promptly } \\
\text { convertible }\left(\mathrm{A}_{2}\right)\end{array}$ & $\begin{array}{l}1125 \text { (up to } 12 \text { months), } 1130 \text { - } \\
1155 \text { (except for 1136), } 1190\end{array}$ & $\begin{array}{l}\text { Short-term } \\
\text { liabilities }\left(\mathrm{L}_{2}\right)\end{array}$ & $\begin{array}{l}1600,1605,1610,1660, \\
1665,1690,1700\end{array}$ & $\mathrm{~A}_{2} \geq \mathrm{L}_{2}$ \\
\hline $\begin{array}{l}\text { Assets slowly } \\
\text { convertible }\left(\mathrm{A}_{3}\right)\end{array}$ & $\begin{array}{l}1100,1110,1125 \text { (over } 12 \\
\text { months), } 1170 \text { (short-term), } \\
1200\end{array}$ & $\begin{array}{l}\text { Long-term } \\
\text { liabilities }\left(\mathrm{L}_{3}\right)\end{array}$ & 1595 & $\mathrm{~A}_{3} \geq L_{3}$ \\
\hline $\begin{array}{l}\text { Assets not easily } \\
\text { convertible }\left(\mathrm{A}_{4}\right)\end{array}$ & $\begin{array}{l}1095,1170 \text { (long-term), } 1200 \\
\text { (those that do not meet the } \\
\text { criteria for "held for sale" } \\
\text { designation) }\end{array}$ & $\begin{array}{l}\text { Permanent } \\
\text { liabilities }\left(\mathrm{L}_{4}\right)\end{array}$ & 1495 & $\mathrm{~A}_{4} \leq \mathrm{L}_{4}$ \\
\hline
\end{tabular}

By matching the values of respective categories of assets and liabilities identified, we now can assess the current and prospective solvency of a company. For instance, we can measure the current liquidity by comparing the sum of two most easily marketable asset groups $\left(A_{1}+A_{2}\right)$ against the sum of immediate and short-term liabilities $\left(\mathrm{L}_{1}+\mathrm{L}_{2}\right)$. If the sum of easily marketable assets is greater than the sum of immediate and short-term liabilities, i.e., $\left(\mathrm{A}_{1}+\mathrm{A}_{2}\right)>\left(\mathrm{L}_{1}+\mathrm{L}_{2}\right)$, the company has adequate liquidity in the current time period. If the statement has an opposite sign, it means that the company does not have sufficient working capital; it faces problems paying its current bills, and is insolvent in the current time period. This is a dangerous state that has to be rectified quickly.

By comparing the value of assets slowly convertible $\left(\mathrm{A}_{3}\right)$ against that of long-term liabilities $\left(\mathrm{L}_{3}\right)$, we can measure the prospective liquidity.

Additionally, by comparing liquidity balances over different periods, we can understand the trends in company's financial situation. 
The second stage of company's liquidity assessment involves calculation and analysis of basic liquidity indices, which are used to assess the company's ability to meet its short-term obligations.

Conclusions and prospects for future research. Liquidity indices are intended to reflect the level of company's solvency in relation to its short-term debts. Therefore, maximum accuracy is important in calculation of these indices, as company managers, lenders, and investors may make crucial decisions on the basis of these results, and the quality of results may have an impact on their bottom line. This further bolsters the importance of company records as a source of additional information during the liquidity assessment process. A proper analysis will, in turn, enable the company to maintain a rational balance of assets and liabilities (funding sources), and keep an adequate amount of cash reserves in order to meet all of its obligations.

The reliability of liquidity indices calculated will facilitate ad-hoc assessment of solvency and understanding of company's financial situation in general. We will further focus our research on systematization of approaches to the organization of company's financial stability assessment.

\section{References}

1. "On Amendments to Methodological guidelines for detecting signs of insolvency of companies and signs of activities aimed at concealment of bankruptcy, fraudulent bankruptcy or deliberate bankruptcy": The Order of Ministry of Economics of Ukraine, No. 1361 of 26.10.2010.

2. "On Approval of methodology for the analysis of financial and commercial operations of public sector companies": The Order of Ministry of Finance of Ukraine, No.170 of 14.02.2006.

3. H. I. Kindratska Economic Analysis: a handbook/ H. I. Kindratska, M. S. Bilyk, A. H. Zahorodnii. $3^{\text {rd }}$ ed. with amendments and additions. - K. : Znannia, 2008. - 487 pages.

4. O. O. Sheremet Financial Analysis: student's guidebook. - K., 2005. - 196 p.

5. Walsh, Ciaran. Key Management Ratios. (Translation from English) - K.:Vseuvyto; Naukova dumka, 2001. - 367 pages.

6. E. H. Melnyk. Classification of deferred expenses: the recording aspect. Materials of 6th International Research and Practice Conference [Aktualne problemy nowoczesnych nauk - 2010] / E. H. Melnyk, I. M. Vyhivska. - Volume 10. Ekonomiczne nauki: Przemyśl. Nauka i studia. - pp. 39-43.

7. $A R(S) 27$ "Non-current assets held for sale and discontinued operations".

8. O. Kravchuk. Non-current assets designated as "held for sale" may be returned to non-current assets // Kravchuk O. "Debit-Credit", No. 48. 2014. - https://online.dtkt.ua/Book/41f11b8b-e1374545-894f-f5ecea0e5d24] 